Хірургічна стоматологія

УДК 617.52:615.847

DOI 10.11603/2311-9624.2016.4.7237

(С). Ю. Домище, В. М. Горицький, Є. Я. Костенко

Ужгородський національний університет

\title{
Систематизація результатів ефективності застосування методу транскраніальної електростимуляції у стоматологічній практиці
}

Резюме. Можливість впливу на процеси загоєння рани шляхом проведення процедур транскраніальної електростимуляції допомагає стабілізувати параметри специфічного та неспецифічного захисту, тим самим створюючи умови для корекції імунологічного статусу як на етапі підготовки до ятрогенного втручання, так і в післяопераційний період, скорочуючи тривалість реабілітації та в окремих випадках, виключаючи необхідність проведення додаткової медикаментозної терапії без ризику виникнення можливих токсичних та алергічних реакцій. У ході системного аналізу можливостей застосування транскраніальної електростимуляції був визначений не тільки значний потенціал методики щодо посилення репаративних процесів організму, а й можливість його застосування при відповідних нервово-м’язових дисфункціях, у процесі моніторингу нервово-функціональної активності, лікування хронічних форм патологій, так як адитивного методу в схемі комплексної реабілітації стоматологічних хворих.

Ключові слова: транскраніальна електростимуляція; загоєння ран; стоматологічне лікування.

М. Ю. Домище, В. М. Горицкий, Е. Я. Костенко

Ужгородский национальный университет

\section{Систематизация результатов эффективности применения метода транскраниальной электростимуляции в стоматологической практике}

Резюме. Возможность влияния на процессы заживления раны путем проведения процедур транскраниальной электростримуляции помогает стабилизировать параметры специфической и неспецифической защиты, тем самым создавая условия для коррекции иммунологического статуса как на этапе подготовки к ятрогенному вмешательству, так и в постоперационный период, сокращая продолжительность реабилитации, и в отдельных случаях, исключая необходимость проведения дополнительной медикаментозной терапии без риска возникновений возможных токсических и аллергологических реакций. В ходе системного анализа возможностей применения транскраниальной электростимуляции был определен не только значительный потенциал данной методики относительно усиления репаративных процессов в организме, но и возможность его применения при соответствующих нервно-мышечных дисфункциях, в процессе мониторинга нервно-функциональной активности, лечении хронических форм патологий, в качестве аддитивного метода в структуре комплексной реабилитации стоматологических больных.

Ключевые слова: транскраниальная электростимуляция; заживление ран; стоматологическое лечение.

M. Yu. Domyshche, V. M. Horytskyi, Ye. Ya. Kostenko

Uzhhorod National University

\section{Systematization of efficacy results during the use of transcranial electrical stimulation method in dental practice}

Summary. The ability to influence the process of wound healing by transcranial electrical stimulation procedures helps to stabilize the parameters of specific and nonspecific protection, thus creating the possibility 
for immune status correction during the preparation for iatrogenic intervention and in the postoperative period, reducing needed time period for rehabilitation, and in some cases eliminating the need for additional drug therapy without the risk of possible toxic and allergic reactions appearance. During systematic analysis of capabilities for transcranial electrostimulation use, it was defined that this method has significant potential not only to enhance the reparative processes of the human body, but also is perspective for application during appropriate neuro-muscular dysfunctions, during the monitoring of neuro-functional activity, for treatment of chronic pathologies, and as the additive method in the structure of complex dental patient rehabilitation.

Key words: transcranial electrostimulation; wound healing; dental treatment.

Вступ. Поширеність патологій щелепнолицевої ділянки, що характеризуються виникненням та прогресуванням відповідних запальних, а в подальшому і гнійних змін, травматичних та ятрогенних ушкоджень, обгрунтовують потребу пошуку адаптованих підходів стоматологічного лікування, які б забезпечували не тільки усунення провокуючого чинника чи купірування основних симптомів, а й відповідні умови для подальшого відновлення функціональної та структурної цілості тканин зубо-щелепного апарату. Відповідно до існуючих фізіологічних концепцій загоєння ран, даний процес складається із чотирьох інтегрованих фаз, що умовно переходять одна в одну: гемостаз, запалення, проліферація та тканинне ремоделювання [3]. Для оптимального розрішення повинна бути збережена не тільки послідовність даних фаз, а й специфічний час їх тривалості та інтенсивність перебігу відповідних процесів. Згідно 3 даними G. Broughton (2006), загоєння ран у дорослих осіб проходить через послідовність шести наступних етапів: гемостазу, запального процесу, мезенхімальної диференціації, проліферації та міграції у ділянку рани, прогресивного ангіогенезу, реепітелізації (відновлення епітеліального покриття над зоною рани), а також синтезу та побудови просторової колагенової сітки, яка забезпечує цілість тканин після загоєння рани [1, 3]. Транскраніальна елетростимуляція (TEC) є одним із методів стимуляції репаративної функції організму на різних етапах відновлення функціональної та анатомічної цілості, що в стоматологічній практиці має особливе значення, оскільки допомагає скоротити загальний час реабілітації, виключити необхідність застосування додаткових медикаментозних препаратів та уникнути ризику виникнення потенційних токсичних та алергічних реакцій $[10,14,15]$. Відтак системний аналіз можливостей та результатів попереднього використання ТЕС у різних напрямках стоматологічного лікування допомо- же верифікувати ефективність даного методу в структурі різних терапевтичних алгоритмів, а також окреслити перспективні вектори його подальшої імплементації.

Метою дослідження було систематизувати існуючі дані щодо ефективності застосування методу транскраніальної електростимуляції у стоматологічній практиці за результатами проведених клінічних та експериментальних досліджень.

Матеріали і методи Добір фактичного текстового матеріалу для проведення деталізованого аналізу здійснювали за допомогою пошукової системи Google Scholar та відповідних науково-метричних та реферативних баз. У процесі систематизації даних відбувалось групування результатів аналізу відповідно до категорій напрямків застосування методу транскраніальної електростимуляції у стоматологічній практиці, принципів порівняння контрольних та досліджуваних груп, фактичних чисельних параметрів та змін показників відповідно до різних підходів проведення комплексного лікування. Обробку наявних попередньо аналітично та типологічно погрупованих чисельних даних проводили за допомогою прикладного програмного забезпечення Microsoft Excel (Microsoft Office, 2013) згідно 3 рекомендаціями О. П. Мінцера, Ю. В. Вороненка, В. В. Власова (2003) [13].

Результати досліджень та обговорення. Переваги транскраніальної елетростимуляції полягають у тому, що даний метод не потребує проведення попереднього імунологічного дослідження, оскільки діє на систему ендогенних опіоїдних пептидів, і не провокує виникнення жодних токсичних чи алергічних ускладнень $[10,11]$. Згідно з даними окремих досліджень, у хворих із відкритими переломами нижньої щелепи відбуваються відповідні імунні зміни: знижується кількість Т-лімфоцитів, підвищується кількість В-лімфоцитів, імуноглобулінів та фагоцитарної активності нейтрофілів, що викликано специфікою імунної реакції орга- 
нізму [21]. На фоні подібних імунологічних змін спостерігається зниження кількості епітеліальних клітин та нейтрофільних лейкоцитів. У ході імунологічного моніторингу було встановлено, що хірургічні методи лікування переломів нижньої щелепи мають супресорний вплив на систему імунітету в цілому, порівнюючи дію таких з більш консервативними алгоритмами лікування [15, 21]. В. В. Подольський (2008) встановив, що використання ТЕС при лікуванні відкритих переломів нижньої щелепи має загальний імунорегулювальний ефект, підвищуючи рівень Т-лімфоцитів та знижуючи кількість В-лімфоцитів і циркулюючих імунних комплексів [21]. Крім того, ТЕС впливає і на параметри місцевого імунітету, викликаючи підвищення рівня епітеліальних клітин, знижуючи кількість нейтрофільних лейкоцитів, а також впливаючи на вміст імуноглобулінів IgA та IgM. Поміж тим, TEC також сприяє профілактиці запальних ускладнень, що є поширеними під час та після лікування переломів нижньої щелепи.

У свою чергу, Е. В. Фомичев та співавт. (2013) відмітили позитивний вплив транскраніальної електростимуляції на групу вибірки 3 47 пацієнтів із наявними в'ялоперебігаючими флегмонами щелепно-лицевої ділянки [16]. Дослідники відмітили, що застосування ТЕС сприяє зниженню показників інтерлейкіну 1-бета, підвищенню рівня інтерлейкіну-4 та зниженню рівня фактора некрозу пухлинальфа на 12-13 день лікування. Зареєстрована динаміки зміни вищеописаних показників свідчить, що ТЕС має доказовий вплив на нормалізацію загального імунітету, зменшує загальний час гноєвиділення та активізує регенераторні потенціали рани в щелепнолицевій ділянці. Е. В. Ефимова (2012) спостерігала скорочення терміну гноєвиділення до 5,1 дня, часу появи грануляцій - до 6,3 дня, розсмоктування інфільтрату - до 8,1 дня, і появу крайової епітелізації - на 10,7 дня у хворих із в'ялоперебігаючими флегмонами щелепно-лицевої ділянки при використанні ТЕС як складового елементу комплексної терапії [11]. Автор дійшла до висновку, що 10 сеансів ТЕСтерапії тривалістю 30 хв сприяють оптимізації процесу загоєння ран та скорочують терміни стаціонарного лікування. Таким чином, включення даного методу в комплексну схему реабілітації стоматологічних хворих із ураженнями максило-фацилярної ділянки сприяе оптимізації процесу лікування та прискорен- ню загального одужання пацієнтів. Проводячи вивчення впливу ТЕС в експериментальних умовах на тваринах з ятрогено змодельованою формою фіброзного анкілозу, А. Н. Сидоренко (2012) також виявив, що такий терапевтичний підхід сприяє нормалізації балансу про- і протизапальних цитокінів, шляхом зниження рівня ІЛ-1 $\beta$ та ІЛ-6 і підвищення рівня ІЛ-10 та бета-ендорфінів [18]. Для контролю пропонованих схем лікування дослідники все ж радять проводити імунологічний скринінг, тим самим забезпечуючи можливість прогнозу захворювання і необхідного об’єму імунокорекції.

У ході проведення окремих досліджень також було виявлено, що транскраніальна електростимуляція має вагомий імунокорегувальний ефект, суть якого полягає у підвищенні кількості Т-лімфоцитів та зменшенні кількості В-лімфоцитів, а також допомагає нормалізувати вміст імуноглобулінів у ротовій рідині, стабілізуючи їх показники уже на 14 день лікування [10]. Порівняльний аналіз, який провів автор, виявив, що при лікуванні хронічного генералізованого пародонтиту середнього ступеня тяжкості у стоматологічних хворих, поліпшення стану пацієнта при імплементації в загальний протокол лікування ТЕС спостерігалось уже на 10-й день лікування, разом з тим, як при проведенні класичного алгоритму лікування - на 14-й день, при чому різниця між даними показниками була статистично значимою. Таким чином, проведення хірургічного етапу лікування хронічного генералізованого пародонтиту рекомендовано тільки на 14-21 день від початку реабілітації, попередньо забезпечивши сеанси ТЕС-терапії з метою корекції та нормалізації імунологічних показників. А. А. Кондратьева (2013) відмітила, що хоч у пацієнтів із хронічним генералізованим пародонтитом після операційних втручань зниження рівня активності пероксидази ротової рідини до показників норми спостерігається і при традиційному протоколі лікування і при застосування ТЕС, проте використання останнього сприяє регенерації ран після ятрогенних маніпуляцій у більш короткі строки, а також виключає потребу прийому додаткових аналгетичних препаратів. Чисельні показники пероксидази, як діагностичного маркера запального процесу у хворих при проведенні TEC, на 9 день зменшилась до 40,6 \%, порівняно $з$ 61,43 \%, що були зареєстровані у хворих після проведення традиційного методів лікування [12]. Автор запропонувала навіть від- 
повідну схему використання ТЕС після проведення операцій на тканинах пародонта, що складалась 35 сеансів ТЕС-терапії через день, тривалістю півгодини біполярним струмом силою в 1,0-2,0 мА.

D. Kirsch та B. Smith (2000) у системному огляді методів лікування хронічного болю провели аналіз можливостей застосування краніальної електротерапії у стоматологічній практиці. В ході аналізу було визначено, що використання запропонованого фізіотерапевтичного підходу дозволяє зменшити больову чутливість на 90 \% у 76 \% пацієнтів без проведення додаткової анестезії при виконанні різних стоматологічних маніпуляцій [5]. У дисертаційній роботі Е. Е. Васенева (1997) відмічено, що ТЕС дозволяє отримати хороший терапевтичний ефект при купіруванні стомалгії (у 62 \% пацієнтів), і задовільний результат ще у третини досліджуваних хворих групи вибірки (36 \%) [9]. О. Я. Мокрик та М. Р. Назаревич (2012) відмітили значимість методу ТЕС не тільки як підходу до реалізації впливу на ноцицептивну систему, а й підкреслили його седативну та імунокорегувальну дії [14]. Подібний комплексний ефект методики базується на нормалізації відповідних центрів адаптаційної системи організму до різних внутрішніх та зовнішніх змін через вплив нейрогормонів та клітинної взаємодії.

С. В. Баркова (2007) у авторському дисертаційному дослідженні відмітила, що застосування ТЕС скорочує строк нормалізації стану слизової оболонки порожнини рота у хворих 3 червоним плескатим лишаєш, про що свідчили отримані результати цитологічних досліджень, а період ремісії при застосуванні TEC був майже вдвічі довшим, ніж такий при стандартній медикаментозній терапії: при типовій формі лишаю 8 і 4 місяці відповідно, при ексудативно-гіперемічній - 8,35 і 4,5 відповідно, при ерозивно-виразковій - 6,75 і 3,5 місяця відповідно [7, 8]. В. Ү. Liu та співавт. (2007) описали також значимість транскраніальної електричної стимуляції як методу моніторингу цілості відповідних нервових структур обличчя після виконання операційних втручань у ділянці основи черепа з приводу пухлинних утворень [4]. У результаті проведеного аналізу, даний метод був рекомендований вченими як достатньо надійний для визначення прогнозу післяопераційних нервових ускладнень - паралічу лицевого нерва різних форм тяжкості. У більш ранніх роботах (G. Frisardi
(1999)) навіть було описано метод отримання оклюзійної шини шляхом транскраніальної електростимуляції з досягнення повного електроміографічного балансу м'язів за відсутності незворотної суглобової патології [2]. Дія електричного імпульсу сприяє реєстрації відповідного співвідношення щелеп, що є найбільш оптимальним у ланцюгу нервово-м’язового балансу щелепно-лицевого апарату, проте недолік подібної техніки заключається у тому, що 3 відповідними вихідними параметрами апарату, адаптованими до потреб реєстрації, даний метод провокує неприємні больові відчуття у пацієнта, через що не може бути рекомендований для впровадження у широку практику. А. Л. Сидоренко та співавт. (2013) також досліджували зміну функціонального стану жувальних м'язів у хворих із нейром'язовою дисфункцією скронево-нижньощелепних суглобів при проведенні традиційного міогімнастичного лікування та прийомі медикаментозних препаратів, та при включенні в алгоритм реабілітації ТЕС-терапії. Традиційні методи лікування навіть через місяць після їх застосування в ході реабілітації не дозволяють значно знизити амплітуду біоелектричних потенціалів у стані відносного фізіологічного спокою, просте ТЕСтерапія дозволяє редукувати дані показники майже у 2 рази. При жуванні ріст потенціалів спостерігався в обох групах, хоча у досліджуваній такий вміст був більш статистично вираженим. В кінці лікування із застосування ТК-електростимуляції вдалось досягти амплітуди потенціалів при максимальному стисненні щелеп до 98 \% від показників норми, при чому позитивна динаміка лікування була зареєстрована і повторена через півроку після активної фази реабілітації $[17,18]$. Вочевидь, подібні зміни пов'язані з нейрогуморальним ремоделюванням, що відбувається в організмі стоматологічного хворого під дією транскранільної стимуляції. У пізніших роботах А. Л. Сидоренко (2013) також було відмічено, що використання нових ортопедичних апаратів, механотерапії та обов'язкового застосування ТЕС сприяе нормалізації співвідношення внутрішньосуглобових елементів та ix комплексній функції у процесі лікування дисфункціональних змін СНЩС, деформуючого артрозу та анкілозу. Таким чином, вдалось поліпшити якість лікування та скоротити строки реабілітації майже на 36,5 \%, паралельно зменшивши ризик виникнення ранніх рецидивів патології [19, 20]. А. М. Воробьев

ISSN 2311-9624. Клінічна стоматологія. 2016. № 4 
та співавт. (2012) запропонували експериментальну схему дослідження впливу ТЕС на процес остеоінтеграції дентальних імплантатів, таким чином визначаючи характер процесу ремоделювання периімплантатної кісткової тканини за особливостями морфологічної структури і гістологічного аналізу у відповідні строки реєстрації змін.

A. Tamkus та K. Rice (2012) виявили, що внаслідок дії транскраніальної стимуляції та моніторингу у хворих можливе виникнення таких ускладнень, як прикушення язика, губи та сколи емалі центрального різця [6]. Подібні ускладнення, згідно з даними проведених досліджень, були зареєстровані лише у 0,63 \% хворих, однак майже у четвертини таких вони мали тяжкий характер, що обгрунтовує доцільність використання накусочних блоків при виконанні електростимулювальної маніпуляції, адекватний дизайн розробки яких досі залишається актуальним питанням для дослідження.

Висновки. Загоєння ран різної етіології щелепно-лицевої ділянки є комплексним динамічним процесом, що проходить через ряд послідовних фаз, у ході яких відбувається не тільки біологічне очищення ділянки ураження, а й відновлення структурно-функціональної цілості тканин зубо-щелепного апарату. Проведення хірургічних маніпуляцій провокує зміну імунологічного статусу організму та

\section{Список літератури}

1. Broughton G. The basic science of wound healing / G. Broughton, J. E. Janis, C. E. Attinger // Plastic and reconstructive surgery. - 2006. - Vol. 117. - № 7 Suppl. P. 12-34S.

2. Frisardi G. The use of transcranial stimulation in the fabrication of an occlusal splint / G. Frisardi // The Journal of prosthetic dentistry. - 1992. - Vol. 68. № 2. - P. 355-360.

3. Guo S. Factors affecting wound healing / S. Guo, L. A. DiPietro // Journal of dental research. - 2010. Vol. 89. - №. 3. - P. 219-229.

4. Intraoperative facial motor evoked potentials monitoring with transcranial electrical stimulation for preservation of facial nerve function in patients with large acoustic neuroma / B. Y. Liu, Y. J. Tian, S. L. Liu [et al.] // Chinese Medical Journal - Beijing English Edition. - 2007. - № 120 (4). - P. 323.

5. Kirsch D. L. The use of cranial electrotherapy stimulation in the management of chronic pain: a review/ D. L. Kirsch, R. B. Smith // Neuro Rehabilitation. - 2000. Vol. 14. - № 2. - P. 85-94.

6. Tamkus A. The incidence of bite injuries associated with transcranial motor-evoked potential monitoring / потенціює існуючий дисбаланс факторів специфічної та неспецифічної резистентності, викликаний первинним впливом патології на відповідних етапах лікування, хоча з точки зору віддаленої перспективи сприяє швидшому прогресивному одужуванню пацієнта, забезпечуючи елімінацію провокуючих чинників та відновлення цілості тканинного біологічного бар’єра. Можливість впливу на процеси загоєння рани шляхом проведення процедур транскраніальної електростимуляції допомагає стабілізувати параметри специфічного та неспецифічного захисту, тим самим створюючи можливість для корекції імунологічного статусу як на етапі підготовки до ятрогенного втручання, так і в постопераційний період, скорочуючи тривалість реабілітації та в окремих випадках виключаючи необхідність проведення додаткової медикаментозної терапії без ризику виникнення можливих токсичних та алергічних реакцій. Крім того, в ході системного аналізу можливостей застосування транскраніальної електростимуляції був відмічений не тільки значний потенціал методики щодо посилення репаративних процесів організму, а й можливість його застосування при відповідних нервово-м'язових дисфункціях, у процесі моніторингу нервово-функціональної активності, лікування хронічних форм патологій, та як адитивного методу в схемі комплексної реабілітації стоматологічних хворих.

A. Tamkus, K. Rice //Anesthesia \& Analgesia. - 2012. Vol. 115. - № 3. - P. 663-667.

7. Баркова С. В. Динамика репаративных процессов слизистой оболочки полости рта у больных красным плоским лишаем на фоне комплексного лечения с применением транскраниальной электростимуляции / С. В. Баркова // Труды ВолГМУ. 2005. - T. 61. - С. 301-303.

8. Баркова С. В. Эффективность применения транскраниальной электростимуляции с целью коррекции психофизиологического статуса больных красным плоским лишаем слизистой оболочки полости рта / С. В. Баркова // Вестник Волгоградского государственного медицинского университета. 2007. - № 1 (21). - С. 35-37.

9. Васенев Е. Е. Транскраниальная электростимуляция в комплексном лечении стомалгии : автореф. дисс. на соискание уч. степени канд. мед. наук : спец. 14.00.21 / Е. Е. Васенев. - Волгоград, 1997. - 24 с. 10. Досвід застосування транскраніальної стимуляції у щелепно-лицевій хірургії / М. Р. Назаревич, Р. 3. Огоновський, В. М. Горицький [та ін.] // Науковий вісник Ужгородського університету. - Серія : Медицина, 2015. - № 1. - С. 210-212. 
11. Иммунокоррегиющий эффект транскраниальной электростимуляции у больных с вялотекущей флегмоной челюстно-лицевой области / Е. В. Фомичев, А. Т. Яковлев, Е. В. Ефимова, Т. В. Морозова // Волгоградский научно-медицинский журнал. 2000. - № 4. - С. 52-54.

12. Кондратьева А. А. Динамика активности пероксидазы ротовой жидкости у пациентов после оперативных вмешательств на тканях пародонта при традиционном лечении и использовании транскраниальной электростимуляции / А. А. Кондратьева, Б. Т. Мороз, Ю. А. Безручко // Вестник Новгородского государственного университета им. Ярослава Мудрого. - 2012. - №. 66. - С. 97-99.

13. Мінцер О. П. Оброблення клінічних і експериментальних даних у медицині : навч. посіб. / О. П. Мінцер, Ю. В. Вороненко, В. В. Власов. - К. : Вища школа, 2003. - 350 c.

14. Мокрик О. Я. Сучасні досягнення фізіотерапевтичного лікування больового синдрому у хворих із патологічними процесами в щелепно-лицевій ділянці / О. Я. Мокрик, М. Р. Назаревич // Медична гідрологія та реабілітація. - 2012. - Т. 10, № 1. - С. 19-23.

15. Назаревич М. Р. Вплив транскраніальної електростимуляції на гостру запальну реакцію у хворих із переломами виличних кісток та дуг / М. Р. Назаревич, I. І. Стадович // Клінічна стоматологія. - 2014. № 1. - С. 51-53.

16. Оптимизация лечения вялотекущих флегмон челюстно-лицевой области: роль немедикаментозной иммунокоррекции / Е. В. Фомичев, А. Т. Яковлев, Е. В. Ефимова, Т. В. Морозова // Вестник Волгоградского государственного медицинского университета. - 2014. - № 4 (52). - С. 78-82.
17. Сидоренко А. Н. Диагностика и совершенствование комплексного лечения больных с нейромускулярным дисфункциональным синдромом височно-нижнечелюстных суставов / А. Н. Сидоренко // Казанский медицинский журнал. - 2012. Т. 93, № 4. - С. 627-631.

18. Сидоренко А. Н. Клинические признаки, диагностика и комплексное лечение больных с деформирующим артрозом височнонижнечелюстного сустава / А. Н. Сидоренко // Казанский медицинский журнал. - 2012. - Т. 93, № 5. - С. 753-757.

19. Сидоренко А. Н. Сравнительный анализ функционального состояния жевательных мышц у больных с нейромышечной дисфункцией височнонижнечелюстных суставов при традиционном методе лечения и применении транскраниальной электростимуляции / А. Н. Сидоренко, А. А. Кулаков, А. Х. Каде // Фундаментальные исследования. - 2013. № 9-1. - С. 132-136.

20. Сравнительный анализ функционального состояния жевательных мышц у больных с дисфункцией височно-нижнечелюстных суставов с сагиттальными и трансверзальными сдвигами нижней челюсти при традиционном методе лечения и применении транскраниальной электростимуляции / А. Н. Сидоренко, А. Х. Каде, В. Оноприев [и др.] // Кубанский научный медицинский вестник. - 2000. № 1 (150). - С. 102-106.

21. Фомичев Е. В. Влияние транскраниальной электростимуляции на клинико-иммунологические показатели у больных с переломами нижней челюсти / Е. В. Фомичев, А. Т. Яковлев, В. В. Подольский // Вестник Волгоградского государственного медицинского университета. - 2008. - № 3 (27). - С. 29-33.

Отримано 13.10.16 